\title{
Fish debris and rare-earth deposition event in the latest Eocene revealed by osmium isotope stratigraphy
}

\author{
JUNICHIRO OHTA ${ }^{1,2,3}$, KAZUTAKA YASUKAWA ${ }^{1,3,2}$, \\ TATSUO NOZAKI ${ }^{3,1,4,2}$, YUTARO TAKAYA ${ }^{5,2,3}$, KAZUHIDE $^{2}$ \\ MIMURA ${ }^{1}$, KOICHIRO FUJINAGA ${ }^{2,1}$, KENTARO \\ NAKAMURA ${ }^{1}$, YOICHI USUI ${ }^{3}$, JUN-ICHI KIMURA ${ }^{3}$, QING \\ $\mathrm{CHANG}^{3}$ AND YASUHIRO KATO ${ }^{1,2,3 *}$ \\ ${ }^{1}$ The University of Tokyo \\ ${ }^{2}$ Chiba Institute of Technology \\ ${ }^{3}$ Japan Agency for Marine-Earth Science and Technology \\ ${ }^{4}$ Kobe University \\ ${ }^{5}$ Waseda University \\ (*correspondence: ykato[at]sys.t.u-tokyo.ac.jp) \\ (First author: junichiro.ota[at]sys.t.u-tokyo.ac.jp)
}

Microscopic fish skeletal debris (fish teeth, denticles, and bones) are the only fossil remains well preserved in pelagic brown clay in which calcareous and siliceous nannofossils are hardly preserved. Since pelagic brown clay deposited in world wide areas of open ocean, fish debris can be a biological proxy in these areas. In addition, fish debris highly concentrates rare earth element after deposition. Thus, fish debris-rich deep-sea sediment is now recognized as a new deep-sea resource for rare earth elements [1].

In 2013, a deep-sea sediment extremely enriched in fish skeletal debris and rare earth elements was found in western North Pacific $[2,3]$. The maximum contents of fish debris and rare earth elements were reported to be $\sim 30 \%$ and $\sim 7000 \mathrm{ppm}$, respectively [2,3]. To unravel the causes of the anomalous accumulation of fish debris and rare earth elements, we determined the depositional age of this fish debris-rich sediment based on osmium isotope stratigraphy. Depositional ages of sediment samples can be obtained by comparing the measured osmium isotope ratios $\left({ }^{187} \mathrm{Os} /{ }^{188} \mathrm{Os}\right)$ in the samples with the reconstructed seawater ${ }^{187} \mathrm{Os} /{ }^{188}$ Os curve [4].

Our osmium isotope measurement and age assignment revealed that the deposition of the fish debris-rich sediment was contemporaneous with the first appearance of the Antarctic ice-sheet in the latest Eocene. In the presentation, we will discuss about causal relationship between the initial growth of Antarctic ice-sheet and the fish debris accumulation in the latest Eocene.

[1] Takaya et al. (2018) Sci. Rep. 8, 5763.

[2] Iijima et al. (2016) Geochem. J. 50, 557-573.

[3] Ohta et al. (2016) Geochem. J. 50, 591-603.

[4] Peucker-Ehrenbrink \& Ravizza (2012) In Geologic Time Scale 2012, 145-166. 